\title{
The Högdalen urban farm: a real case assessment of sustainability attributes
}

\author{
Rebecka Milestad $^{1}$ (D) $\cdot$ Annika Carlsson-Kanyama ${ }^{1} \cdot$ Christina Schaffer $^{2}$
}

Received: 14 June 2019 / Accepted: 8 May 2020 / Published online: 21 May 2020

(C) The Author(s) 2020

\begin{abstract}
While urban indoor farming is a fairly new phenomenon, there is a growing interest from producers, authorities and consumers alike. However, many assumptions are made, and expectations held, about urban indoor farming from a sustainability, food production and food provisioning point of view. These assumptions and expectations need to be tested and assessed. This study assessed greenhouse gas (GHG) emissions and a number of social aspects of a newly established indoor urban farm in Stockholm. The farm was the result of a project created by commercial, civil society and municipal actors with the aim to make use of unused urban space, create jobs and produce food. While lettuce grown on the indoor farm emitted more GHG than lettuce cultivated outdoors in Sweden, it was more climate friendly than imported lettuce in our comparison. Furthermore, the indoor farm created value for the actors involved and for the city district, albeit on a small scale. Many of the positive environmental and social features owed to the small scale of the indoor farm and the context in which it developed. Thus, when evaluating production systems like this one, we need to be cautious and refrain from extrapolating the results.
\end{abstract}

Keywords Sustainable food production $\cdot$ Indoor farming $\cdot$ Urban agriculture $\cdot$ Temperate areas $\cdot$ Stockholm, Sweden.

\section{Introduction}

Traditional forms of indoor farming, such as conventional greenhouse cultivation, still dominate the market globally in terms of space with 496,800 ha (Hortidaily 2019), but novel forms under various names have emerged in the last decade in the global North. These include vertical farming (VF) (Despommier 2010), zero-acreage farming (Zfarming) (Specht et al. 2014) and the closely related buildingintegrated agriculture (BIA) (Gould and Caplow 2012).

Rebecka Milestad

rebecka.milestad@abe.kth.se

Annika Carlsson-Kanyama

annika.carlsson-kanyama@ecoloop.se

Christina Schaffer

christina.schaffer@natgeo.su.se

1 Department of Sustainable Development, Environmental Sciences and Engineering, Royal Institute of Technology - KTH, Stockholm, Sweden

2 Department of Physical Geography, Stockholm University, Stockholm, Sweden
Various cultivation techniques are used on these farms - for example, both in-soil and soil-less cultivation are found (AlKodmany 2018). In all cases, crops are grown not in soil on the ground, but in pots or in hydroponic systems. Thus, no (farm) land is needed for this type of agriculture, which is one of the main advantages cited by advocates (Despommier 2010). Urban soil can be contaminated, which is avoided if cultivation occurs indoors (Lovell 2010). Furthermore, outdoor cultivation competes with housing and other uses of urban green space needed in growing metropolitan areas. In shrinking cities, outdoor urban agriculture can be a use for vacant land as in the case of Detroit, US (Viljoen and Bohn 2014) and indoor farms can make use of unlet space in buildings (Grewal and Grewal 2012). In cities concerned with their food provisioning, urban farms in and on buildings can contribute to food production for the city, which is mirrored in the emergence of 193 North American Food Policy Plans (Morgan 2015). In addition, claims are also made about how urban indoor farming can contribute to fulfilling sustainability goals (Despommier 2009; Germer et al. 2011; Benke and Tomkins 2017).

Indeed, in the academic literature, many assessments have been made of the potential of indoor farming in terms of sustainability performance and the amounts of food that 
can be produced. For example, Despommier (2009) argues that since the world's population is increasing and conventional farming is detrimental to the environment, food should be grown in multi-storey vertical farms in cities. This would free up land in rural areas and enable natural ecosystems to recover, he argues (ibid). Less water and energy would be needed (Al-Kodmany 2018), and the use of fossil fuels would decrease due to less use of machines in conventional farming and less transportation as food was produced locally (ibid). According to Kalantari et al. (2017), increased vertical farming would help reduce both starvation and climate change. These authors address the potential efficiency of use of space and resources to produce high quantities of food in high technological systems in Controlled Environmental Agriculture (CEA) throughout the year. In most cases, the main crops are leafy greens, tomatoes and strawberries (Agrilyst 2017; Benke and Tomkins 2017). However, much less has been written on assessments of real cases (e.g. Astee and Kishnani 2010; Orsini et al. 2014; Graamans et al. 2018; Semilla et al. 2018), and thus little is known about the overall contribution of urban indoor farming in relation to food provision and sustainability goals. Such assessments are needed if we are to understand the possible benefits of indoor farms and whether policy makers should incorporate these types of farms into urban food strategies (Mok et al. 2014). Urban indoor farms range from smallscale cultivation chambers to large-scale "skyscraper farming" (Specht et al. 2014; Al-Kodmany 2018). Thus, as stated by Eigenbrod and Gruda (2015), they need to be assessed in their different contexts, in terms of scale of production, technology used, crops grown, business models and rationale for being developed. Indoor farming could in practice be as unsustainable as conventional agriculture (Specht et al. 2014).

The impacts of climate change due to human-induced emissions of GHG are already seen in many parts of the world, and in order to mitigate further change a significant cut in emissions is needed before 2030. In its latest report, the IPCC (2018) states that "global net human-caused emissions of carbon dioxide (CO2) would need to fall by about 45\% from 2010 levels by 2030, reaching 'net zero' around 2050 " (p.1). Due to this challenge, it is of importance to study whether or not the new production method of indoor urban farming contributes to this endeavour.

We contribute to the discussion on the possible advantages and disadvantages of urban indoor farming by assessing an existing indoor urban farm in the city district of Högdalen, Stockholm. The question that guided our research was: how does the Högdalen indoor urban farm perform in terms of social and environmental criteria? More specifically, we assess GHG emissions compared with other production systems, and discuss a number of social and economic aspects of this urban indoor farm.
We start with an overview of the literature on aspects of urban farming and then go on to detail the methods used in the study. We then present the results and finish with a discussion on the guiding questions.

\section{Different types of urban indoor farming and their (claimed) performance}

\subsection{Types of indoor farms}

One type of indoor farm is the vertical farm, in which plants (and animals) are cultivated on multiple levels (Despommier 2010). Vertical farms can be integrated into buildings originally not purposed for agriculture, they can be (greenhouses) placed on buildings or they can be "skyscraper farms". These latter 30-storey versions only exist as models and plans (Despommier 2009; Kalantari et al. 2017; Al-Kodmany 2018). The three main techniques used in vertical farming are hydroponics, aeroponics and aquaponics, often in combination with computerised or automated systems including artificial light (Al-Kodmany 2018). According to Beacham et al. (2019), knowledge generation on vertical farming is led by industries, and data is often based on marketing from the private sector, and is not available for academic scrutiny.

Another type of urban farming encompassing indoor farms is the "zero-acreage farming" (Zfarming) a concept coined by Specht et al. (2014). Zfarming are forms of farming that do not use farmlands or open space. This includes rooftop gardens and greenhouses, edible green walls, indoor farms and vertical greenhouses (Specht et al. 2014). A large proportion of forms of such farms seem to be located in North America, followed by Asia (Thomaier et al. 2015; Agrilyst 2017; Al-Kodmany 2018). Thomaier et al. (2015) suggested five different categories of Zfarms: commercial, image-oriented, social and educational, for urban living quality, and as innovation incubator. They conclude that this type of food production can only provide a small share of the overall food demand, for instance fresh fruits that are sensitive to long-distance travel (ibid).

For the purposes of this paper, indoor urban farming is understood as cultivation in premises with no sun light (such as a garage, an attic or an abandoned factory building), thus excluding cultivation in urban greenhouses where environmental impacts during cultivation are most likely similar to those in greenhouses in peri-urban areas or in the countryside.

\subsection{Sustainability performance of indoor farms}

There are far-reaching claims as to the sustainability performance of indoor farms (Benke and Tomkins 2017). For example, indoor farms are said to reduce food miles, air pollution, water use and the need for fertilisers and pesticides, as well as 
using space more efficiently and conserving nature (e.g. Despommier 2009; Kalantari et al. 2017; Al-Kodmany 2018).

There have only been a few previous attempts to measure GHG emissions from existing indoor urban farms. Shiina et al. (2011) found that the total $\mathrm{CO} 2$ emissions from cultivating leafy greens in an existing plant factory in Japan with no daylight amounted to $6.4 \mathrm{~kg}$ of $\mathrm{CO} 2$ per $\mathrm{kg}$ of leaf lettuce production, and the amount of $\mathrm{CO} 2$ emissions from lighting and air conditioning (electricity use) tended to be large, at $90 \%$. The same authors assumed that the electricity generation result is $378 \mathrm{~g}$ of $\mathrm{CO} 2$ per $\mathrm{kWh}$. This may be compared to the Nordic average electricity generation, which is estimated at $50 \mathrm{~g}$ of $\mathrm{CO} 2$ equivalents per $\mathrm{kWh}$ (Energi och klimatrådgivningen 2019).

Burgos and Stapel (2018), who studied lettuce production in vertical farming, found that $1 \mathrm{~kg}$ of lettuce contributed $5.7 \mathrm{~kg}$ of $\mathrm{CO} 2$ equivalents. Energy inputs accounted for the highest source of $\mathrm{CO} 2$ emissions in current vertical farming, $90 \%$. The same authors also created a scenario for improved vertical farms, emitting 0.16 to $0.33 \mathrm{~kg}$ of $\mathrm{CO} 2$ equivalents per $\mathrm{kg}$ of lettuce. Data for green vertical farms was partly based on theoretical values.

Molin and Martin (2018), who studied vertical hydroponic farming of basil, found that the carbon footprint was $3.9 \mathrm{~kg}$ of $\mathrm{CO} 2$ equivalents per $\mathrm{kg}$ basil in a plastic pot. Emissions from electricity production were assumed to be $100 \mathrm{~g}$ of $\mathrm{CO} 2$ equivalents per $\mathrm{kWh}$ in this study; and roughly $40 \%$ of the total GHG emissions was due to lighting while another $40 \%$ came from the manufacturing of garden soil.

Sweden has a growing season of between four and seven months, meaning that fresh domestically grown vegetables cultivated in the open field are available only during parts of the year. Various solutions exist in order to supply the market with fresh products throughout the year, such as importing vegetables from countries with a warmer climate, (e.g. Spain), or cultivating vegetables in heated and lighted greenhouses, either in Sweden or in a country like the Netherlands. Several studies have compared how energy use and GHG emissions differ between all these products, given the need for transportation and heating of the out-of-season vegetables. The results show that the lowest emissions vegetables are those cultivated domestically on the open ground, while imported vegetables cultivated without heating have lower $\mathrm{CO} 2$ emissions than those grown in greenhouses, even when long-distance transportation is considered (e.g. Hospido et al. 2009; Krewer, Emanuelsson och Zettergren 2013). Emissions from greenhouse cultivation depend to a large extent on the kind of fuel that is used for heating and lighting; fossil fuels such as oil or natural gas produce much higher emissions per $\mathrm{kWh}$ than biofuel and wind power.

The social benefits of indoor farms are said to range from improved food quality to job creation and improved food security (Specht et al. 2014; Al-Kodmany 2018). Economically, reduced costs have been observed from lower inputs of water, use of recycled resources and larger yields (Al-Kodmany 2018). However, high initial costs are also mentioned by some (Benke and Tomkins 2017) as well as high land prices in metropolitan areas (ibid). It is doubtful whether low-income countries would be able to afford the technologies needed for indoor farming, and whether their people could afford the products (Al-Kodmany 2018).

Thomaier et al. (2015) claim that Zfarming contributes to building sustainable cities through social innovation and synergies between buildings and farming. At the same time, "synergies between farming and buildings are not yet fully exploited, probably because most ZFarms are integrated into existing buildings. Existing building infrastructures are not necessarily compatible with the implementation of energy loops or other resource-efficient systems" (Thomaier et al. 2015 p 49).

As for yields, Al-Kodmany (2018) reports a production of leafy greens that is five to ten times greater per unit area compared to conventional production in the Sky Greens Farms in Singapore. Benke and Tomkins (2017) cite the company Verticrop in Vancouver that claims their vertical hydroponic farms can produce the same amount of food on a 50 by $75 \mathrm{ft}$ area of production as a conventional farm of 16 acres. In a model, 37 storey, 0.93 ha vertical farm, Banerjee and Adenaeuer (2014) claim it can support 15,000 people with enough vegetables, fruits and fish. Lettuce produced indoors in the Philippines using LED lights gave better yields due to better protection of the plants from the effects of climate change, such as typhoons, droughts and floods (Semilla et al. 2018).

\subsection{Indoor farming compared to other forms of urban agriculture}

Outdoor urban agriculture, such as allotment gardening, community gardening and home gardening, contributes to urban sustainability in other ways than indoor agriculture. As a part of urban green space, outdoor cultivation provides a habitat for other organisms. On a larger scale, urban outdoor agriculture contributes to the connectivity of the landscape and green corridors in the urban space (Bohn and Viljoen 2011). Urban green space contributes to more direct ecosystem services important for human well-being, such as reduction of noise, air pollutants and mitigation of urban heat island effects (Bolund and Hunhammar 1999; Gómez-Baggethun and Barton 2013). Urban agriculture that includes fruit or nut trees contributes extensively to all categories of ecosystem services (Berghöfer et al. 2011; Bauduceau et al. 2015). The multifunctional benefits and ecosystem services from urban fruit forests have been highlighted by Clark and Nicholas (2013), as well as in Seattle's edible landscape (McLain et al. 2012) and in the green stretches suggested by Bohn and Viljoen (2011) through their concept Continuous Productive Urban Landscape (CPUL). 
Regarding the social benefits of outdoor urban agriculture, community gardens in particular can contribute to social capital (Firth et al. 2011). The health benefits are multidimensional: aside from the physical activity and consumption of fresh food, well-being derives from urban gardens' aesthetic and relational qualities - the relations between gardener-plants, gardener-gardener and gardener-place. The pride that comes from showing the garden to visitors also contributes to increased health and well-being (Hale et al. 2011). The food produced is not necessarily the main benefit: in a study of 50 community gardens in Stockholm, gardeners reported that their reasons for participating in community gardening were because it is fun, socially rewarding, and an expression of environmental consciousness (Bonow and Normark 2018). Community gardens as a form of do-it-your-self urbanism (Finn 2014) enable people to participate in the design of their own neighbourhood. In allotment areas, know-how on gardening practices and ecological knowledge is shared among gardeners and over generations (Barthel et al. 2010). When it comes to food security and resilience of cities, the important points are to preserve arable land and to preserve knowledge about how to produce food among citizens (Barthel et al. 2015). More than 7000 people are active in allotment gardening in Stockholm county (Swedish Allotment Garden Society 2019). In addition, private home gardens constitute $30 \%$ of the land area of Stockholm county (RUFS 2018).

\section{Methods}

This study was part of a larger project funded by Sweden's Innovation Agency (Vinnova). The major parts of the project concerned developing an indoor farm, bringing together actors and thinking ahead on future business models. A smaller part concerned an exploratory assessment of the indoor farm, which is reported in this article. The assessment was performed in two parts. The first concerned the greenhouse gas (GHG) emissions from the indoor farm in comparison to other types of lettuce growing (see below). The second component was a qualitative study of social factors to assess the broader issues related to the sustainability of the farm. This was achieved in two ways: 1) interviews with key actors, combined with 2) field visits and observations. The three key actors were formally interviewed once each. Interviews were semi-structured, and they were recorded and transcribed. The questions dealt with the history of the indoor farm, how the farm worked in practice, interviewees' expectations of the project, potential for improvement, project management and communication, and interviewees' thoughts on the possibility and desirability of scaling up the indoor farm (in Högdalen or in other places). Interviews were carried out during spring 2018 in Stockholm. Each interview took about $1.5-2 \mathrm{~h}$ and was carried out in person. The key participants included the project leader at Invest Stockholm (part of Stockholm municipality), the project manager in Högdalen, and the technical consultant (Table 1). Important information was collected during the project by the two of the authors of this article who were directly involved in the project.

They participated in the opening ceremony of the indoor farm, as well as in a number of study visits, a local conference on urban agriculture, media coverage (e.g. being interviewed in the indoor farm facility), and supervised student essays about the indoor farm and thus met with the involved project participants and workers at numerous occasions during the course of the project.

\subsection{Framework for analysis}

Brunori et al. (2016) suggested an analytical framework for assessing the sustainability of food systems and food value chains. The framework groups 24 attributes in 5 categories or dimensions: economic, social, environmental, health and ethical (see Table 2).

The matrix can be considered a gross list of relevant issues to study when assessing the sustainability performance of a food value chain. While Brunori et al. (2016) developed a number of quantitative or qualitative indicators for each attribute, they are used here for structuring the analysis of sustainability aspects of the indoor farm. The attributes are described in detail in appendix 1 . The framework was used to assess the impact of the indoor farm. All attributes were not relevant, however (e.g. no animals were involved in production). We gave each relevant attribute a score of,+++ , or +++ for different degrees of positive sustainability impact, a $-/+$ for

Table 1 Description of interviewees

\begin{tabular}{|c|c|c|c|}
\hline Code & Function & Organisation & Tasks \\
\hline IP 1 & Project leader & $\begin{array}{l}\text { Stockholm Invest, part of Stockholm } \\
\text { municipality }\end{array}$ & $\begin{array}{l}\text { Holding the whole project together; responsible for communication; applicant in } \\
\text { relation to funder }\end{array}$ \\
\hline IP 2 & Project manager & Nya Rågsveds Folkets Hus (NRFH) & $\begin{array}{l}\text { Responsible for running the indoor farm in Högdalen; using the lettuce; employer of } \\
\text { staff }\end{array}$ \\
\hline IP 3 & $\begin{array}{l}\text { Technical } \\
\text { consultant }\end{array}$ & Arvalla (consulting) & $\begin{array}{l}\text { Deputy project leader; responsible for coordination and provision of technical } \\
\text { content in the indoor farm }\end{array}$ \\
\hline
\end{tabular}


Table 2 Multi-criteria performance framework. Taken from Brunori et al. (2016)

\begin{tabular}{lllll}
\hline Economic & Social & Environmental & Health & Ethical \\
\hline Affordability & Food security & Resource use & Nutrition & Animal welfare \\
Creation \& distribution of added value & Consumer behaviour & Pollution & Food safety & Responsibility \\
Economic development & Territoriality & Biodiversity & Traceability & Fair trade \\
Efficiency & Connection & Technological innovation & & Information \& communication \\
Profitability & Labour relations & Food waste & & Governance \\
Resilience & & & & \\
\hline
\end{tabular}

neutral impact and a "no information" for the attributes that did not make sense for our study or where there was no data. A combination of expert knowledge of the authors, informed by cases reported in literature was the basis for each assessment.

\subsection{Calculating greenhouse gas emissions}

The ambition was to make a rough calculation of the important differences between GHG emissions per kg of harvested lettuce delivered to the cafés from the indoor farm and those from the lettuce previously bought. As previous studies have shown that GHG emissions in indoor farming are dominated by heating and lighting, we focused on gathering data from those processes for the indoor farming and contrasted it with GHG emissions from operations during farming on the open ground. We also calculated transportation emissions and emissions from retail.

The GHG emissions for manufacturing inputs such as seeds, fertilisers and soil were not considered as we did not assume large differences between the two production systems. Likewise, material for constructing greenhouses and machinery was not included, nor was the fabrication of packaging material. The method used was inspired by LCI (life cycle inventory) analysis, and the functional unit in our study was $1 \mathrm{~kg}$ of lettuce delivered to the café in Högdalen. The system boundaries are presented in Table 3.

Data on GHG emissions from the cultivation phase in "conventional" cropping was sought by making a survey of the available literature (mostly LCA or LCI studies) about lettuce grown in the open and in greenhouses (LRF 2003; Hospido et al. 2009). The study from LRF (2003) included data on iceberg lettuce grown in the open in Sweden. The data from Hospido et al. (2009) contained data for Spanish lettuce grown in unheated greenhouses and for lettuce grown in heated greenhouses in the UK, where natural gas was used for heating. Since we could not find any study about lettuce grown in greenhouses in the Netherlands, we used the data from the UK, since the climate is similar and it is common to heat greenhouses with natural gas in the Netherlands (Dutch Greenhouses 2020). Data on the cultivation phase in the indoor farm in Högdalen was collected by analysing electricity bills provided by NRFH, who also provided data about the lettuce yield. Emissions from electricity were calculated based on an assumed mix of nuclear power (10\%), hydropower (70\%) and wind power (20\%), which was what the organisation paid the electricity supplier for. Emission factors for each power source were obtained from Jernkontoret (2018) and the resulting emissions were $6.3 \mathrm{~g}$ of $\mathrm{CO} 2$ equivalents per $\mathrm{kWh}$.

For transportation, we used an available calculator (NTM 2018 ) with added emissions (30\%) for refrigerated transport (Swahn 2008). We assumed that the lettuce from Spain was transported from Murcia to a storage facility close to Stockholm (Årsta) with a trailer of 28-34 ton capacity and then by van from Årsta to Högdalen. For Dutch lettuce, we assumed transportation from Amsterdam to Högdalen with the same types of vehicles as above, and for the Swedish lettuce grown in the open, we assumed transportation from southern Sweden (Malmö) to Högdalen. Emissions from the wholesaler and retailer were based on literature data (LRF 2003) and were assumed to be the same for all lettuces except for the one grown in Högdalen. Other emissions and environmental loadings were not part of the assessment.

\section{Case description}

The indoor farm that is the subject of this study is located in a cellar under a shopping and community centre in Högdalen, a southern suburb of Stockholm. As in most areas in the Swedish capital, Högdalen is currently going through densification due to a shortage of housing. The first modern houses were built here in the 1950s, and the subway started running around the same time. The organisation People's House in Rågsved (NRFH) ${ }^{1}$ runs the indoor farm. NRFH is made up of civil society organisations in the area. The NRFH offers activities for children, youth, the unemployed and the elderly in the area, and lets space to accommodate these activities. It employs people from the area with physical and psychological

\footnotetext{
${ }^{1}$ Rågsved is the name of the neighbouring community, one subway stop from Högdalen
} 
Table 3 Description of variables included and excluded when calculating GHG emissions from various types of lettuce delivered to the café in Högdalen

\begin{tabular}{|c|c|c|c|c|}
\hline Type of lettuce & Variables included & & & Variables excluded \\
\hline $\begin{array}{l}\text { Lettuce from the cellar } \\
\text { in Högdalen }\end{array}$ & & $\begin{array}{l}\text { No emissions were } \\
\text { calculated as the lettuce } \\
\text { is delivered on foot }\end{array}$ & $\begin{array}{l}\text { No emissions were calculated as the } \\
\text { lettuce is not stored before } \\
\text { reaching the cafeteria }\end{array}$ & $\begin{array}{l}\text { Emissions from fabrication of } \\
\text { fertilisers, pesticides, soil, } \\
\text { packaging, etc. }\end{array}$ \\
\hline $\begin{array}{l}\text { Lettuce from the open } \\
\text { ground in Sweden }\end{array}$ & $\begin{array}{l}\text { Emissions due to energy } \\
\text { use for farm operations } \\
\text { incl. Irrigation }\end{array}$ & $\begin{array}{l}\text { Emissions due to } \\
\text { transportation by lorry } \\
\text { to Högdalen }\end{array}$ & $\begin{array}{l}\text { Emissions due to storage at the } \\
\text { wholesaler and retailer }\end{array}$ & $\begin{array}{l}\text { Emissions from fabrication of } \\
\text { fertilisers, pesticides, soil, } \\
\text { packaging, etc. }\end{array}$ \\
\hline $\begin{array}{l}\text { Lettuce from an } \\
\text { unheated } \\
\text { greenhouse in } \\
\text { Spain }\end{array}$ & $\begin{array}{l}\text { Emissions due to heating, } \\
\text { lighting and farm } \\
\text { operations }\end{array}$ & $\begin{array}{l}\text { Emissions due to } \\
\text { transportation by lorry } \\
\text { to Högdalen }\end{array}$ & $\begin{array}{l}\text { Emissions due to storage at the } \\
\text { wholesaler and retailer }\end{array}$ & $\begin{array}{l}\text { Emissions from fabrication of } \\
\text { fertilisers, pesticides, soil, } \\
\text { packaging,etc. }\end{array}$ \\
\hline $\begin{array}{l}\text { Lettuce from a heated } \\
\text { greenhouse in the } \\
\text { Netherlands }\end{array}$ & $\begin{array}{l}\text { Emissions due to heating, } \\
\text { lighting and farm } \\
\text { operations }\end{array}$ & $\begin{array}{l}\text { Emissions due to } \\
\text { transportation by lorry } \\
\text { to Högdalen }\end{array}$ & $\begin{array}{l}\text { Emissions due to storage at the } \\
\text { wholesaler and retailer }\end{array}$ & $\begin{array}{l}\text { Emissions from fabrication of } \\
\text { fertilisers, pesticides, soil, } \\
\text { packaging, etc. }\end{array}$ \\
\hline
\end{tabular}

disabilities, and works together with the municipality, local businesses and civil society organisations to develop the area.

There were many reasons for establishing the indoor farm in Högdalen. First, there was a space under the commercial centre that was hard to find use for - the space had been empty for several years. Second, the real estate owner and the NRFH had come into contact previously and NRFH was already a major tenant in the centre, running a large second-hand shop there. Thus, a good rental deal could be bargained for concerning the basement premises. Third, Högdalen is home to both old types of industrials in Stockholm, and new types such as a biochar plant and a whole cluster of so-called cleantech businesses. Thus, the municipality was interested in developing the farm in this specific place, plus the fact that the southern suburbs needed high-profile projects to increase their value.

The indoor farm was established in the frame of a project with partners from civil society (NRFH), state and municipal agencies (e.g. Stockholm municipality) and businesses (e.g. the real estate owner and a greenhouse business). Two other municipalities in southern Sweden were also involved, with other food production plants in new contexts, as well as smaller start-ups in this business field who got access to exhibition space and business development in all three locations.

The basement premises are not in themselves suitable for cultivation. Thus, a $80 \mathrm{~m}^{2}$ cultivation chamber was built, in which one level of cultivation tables were installed, together with suitable lamps, a water tank with piping, small heaters and humidifiers. Ventilation air from one of the shops in the commercial centre was used to add $\mathrm{CO} 2$ to the cultivation chamber.

The cultivation of lettuce was carried out in the following way: plastics pots were filled with soil and two seeds were planted in each. When the seeds had sprouted (after approximately two days), the pots were put on the cultivation tables (see figs. 1 and 2). The tables were so-called "ebb and flow tables", where water mixed with conventional fertilisers was let on and absorbed into the pots. The leftover water was run back to the water tank. The LED lamps were lit $16 \mathrm{~h}$ a day and during this time no additional heating was needed in the cultivation chamber. During the dark hours, small heaters were used to keep the temperature at a good level for the plants. Superfluous heat was let out via the ventilation system. After four to five weeks, the lettuce was ready to be harvested. Only the leaves were harvested - the pots were cleaned and reused for the next batch of produce. In total, six ebb and flow tables occupied the cultivation chamber and approximately 1000 pots had space to grow at the same time. For the sake of research, only lettuce was produced during the first months of running the indoor farm. However, other types of herbs and leaves could be grown in the same room. There was no use of pesticides in the cultivation.

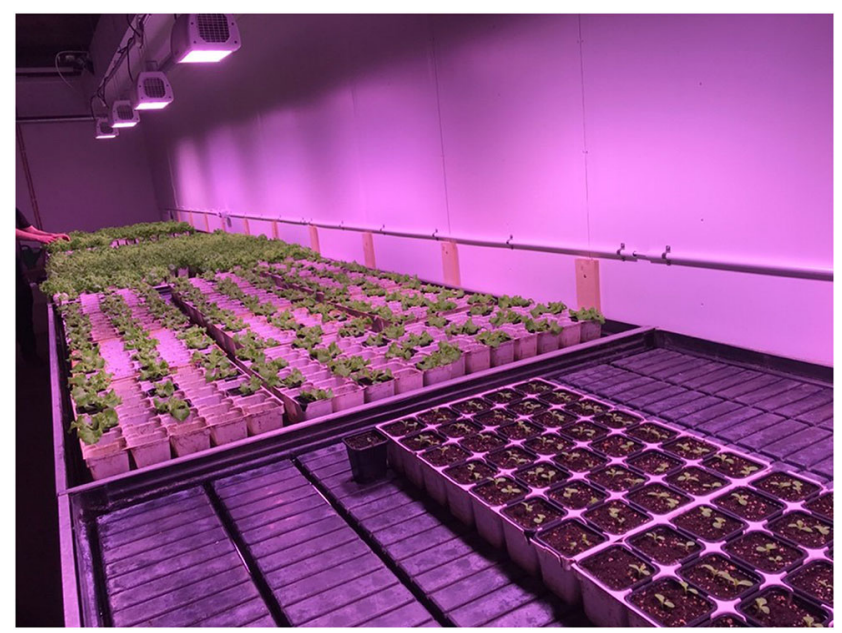

Fig. 1 Photograph of the indoor farm in Högdalen, with lettuce in different stages of development (author's own photo) 
Fig. 2 Simple illustration of the cultivation system in the indoor farm in Högdalen (used with permission from Uppsäll and Enges 2018). The lettuce was delivered on foot, or on the subway, to the NRFH cafés in Högdalen and Rågsved, where it was used to make sandwiches and salads. Previously, the cafés bought lettuce originating from the Netherlands, Spain or Sweden from a wholesaler

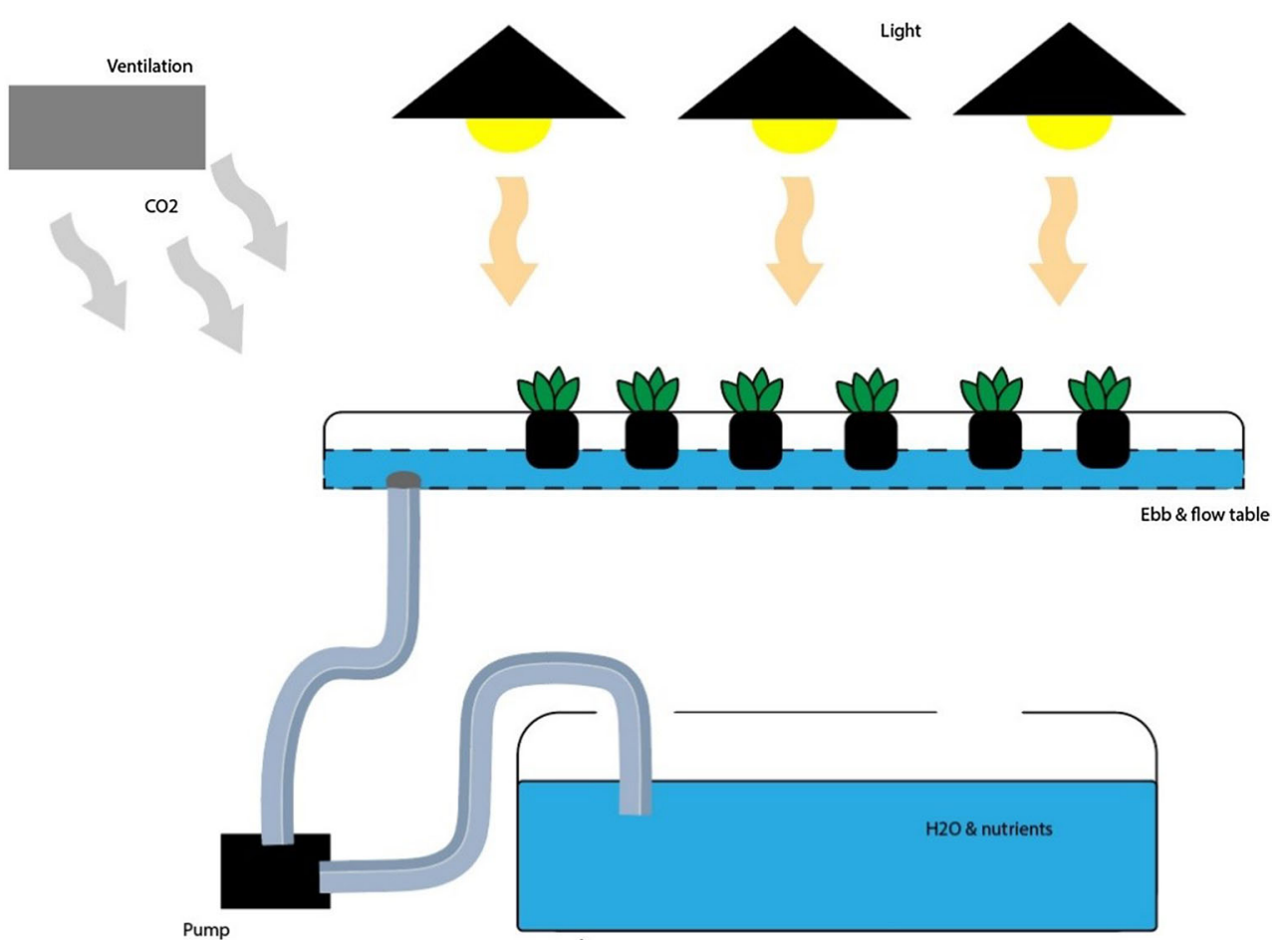

\section{Results}

\subsection{How the indoor farm worked in practice}

Work that was done in the indoor farm included: filling pots with soil, planting seeds in each pot, taking care of the pots during the time seeds germinated, moving pots up on the table, irrigating, harvesting, cleaning the pots, and refilling the pots with soil. It took a bit more than one hour to prepare one of the tables with pots and seeds. The farm also needed to be checked from time to time - lights had to be put on and off, the temperature checked, and nutrients mixed into the water tank. The workers at NRFH were educated in the necessary farming techniques during two days before the launch of the indoor farm by the greenhouse company. Despite this, a number of learningby-doing mistakes were made in the start-up phase of the farm. For example, lights were put on for too few hours a day; seeds were placed too deeply into the pots; no plant nutrients were used in the water; and irrigation was done too infrequently.

The most costly part of the overall production of lettuce was workers' salaries, followed by the electricity for the lamps in the cultivation chamber. According to IP2 and an unpublished market survey in Högdalen, local restaurant owners and consumers said that they were willing to pay extra for the lettuce because it was grown locally. An important reason for this willingness was the fact that there were no transportation emissions involved in the distribution stage of the value chain. The first batch of lettuce was sold at $10 \mathrm{SEK}^{2}$ each in the NRFH second-hand shop in Högdalen and used in its café. This lettuce was not perfect - it was rather small due to cultivation errors. IP2 argued that it should be possible to get up to 20 SEK per lettuce, which is comparable to the price of equivalent products in supermarkets.

Around 100 pots could be harvested each week to fulfil the needs of the NRFH cafés. It was clear from the local interest in the indoor farm that the willingness to buy its products was connected to the fact that it was situated in Högdalen and that it was done in an innovative way. IP2 was continually contacted by interested citizens who wanted to become indoor gardeners, but he could not advise them in the current project phase. There was also a large interest from retailers who wanted to buy the products. However, in the current project phase, it was decided that all produce should be used in the immediate locality, i.e. Högdalen and Rågsved.

The aim of the indoor farm in terms of labour was to create jobs in the transition between publicly funded support measures and real jobs in semi-industrial plants. At the time of the study, two-thirds of the salary for people working in the indoor farm was dependent on public support. Two people were employed to do gardening and marketing work, but not full-time. The gardening activities were not ample enough to support a full-time worker. Rather, as IP2 put it:

$\overline{210 \mathrm{SEK}=1 \text { Euro }}$ 
"It's not the farm in itself but the activities that are created around the farm" (IP2)

that were important to create more jobs. Indeed, he continued, it was not a work-friendly environment, being below ground. It was important to combine the gardening with other tasks:

"We don't want someone to hang around down there" (IP2).

More jobs were created locally since the indoor farm created more tasks to fulfil within the NRFH conglomerate. In addition, a lot of other activities emerged as a consequence of the indoor farm. As IP2 stated:

"I mean, it's enormous what we've done in the form of study visits, lectures, seminars, meetings... a lot of things have happened. And I don't know how many times coffee has been ordered from the second-hand shop café. I mean, an economy is created in this way as well, a secondary economy. But it's actually a rather large economy." (IP2)

Still, the indoor farm could not be profitable on its own and it could not compete with commercial urban greenhouses - it needed additional activities taking place in the larger setting to be able to do so.

The innovation in the project was not the cultivation technology itself, but rather the distribution system (no middle men and no transportation after harvest). An added value was the use of urban space that was not otherwise being used. In an area with a shortage of housing, this could be considered an added value, since more houses could be built above ground.

The indoor farm was not affected by the weather, dogs or other animals, littering or toxic emissions. There were no insects or other pests affecting the cultivars - and if this were to happen, the farm was so small that the cultivation chamber could be easily emptied and cleaned. As in other types of agricultural activities, this farm was dependent on seeds, soil, clean water and nutrients that needed to be brought in, but that also needed to be developed with the help of biodiversity and natural geological processes. There was a large dependence on functioning electricity supply, and thus there was a vulnerability to power-cuts. There were some circulating flows already in the indoor farm, such as $\mathrm{CO} 2$ inflow from the centre facility, use of empty indoor space, reuse of pots, and circulating the water.

A critical point raised by one interviewee was the impression children got of farming when they visited the indoor farm and had had little other experience of food production. In that sense, IP2 felt a responsibility:
"New generations might get a faulty impression of how vegetables are produced [ ] of course, if you drag school children in here [ ] then you have to give them the whole picture about farming" (IP2).

\subsection{Expectations on the indoor farm project}

IP3 claimed that the profit margins could increase by 200-300\% with a direct distribution system such as in Högdalen, compared with conventional greenhouse cultivation in Sweden.

On the municipal level, the indoor farm was a small contribution to the city's fossil-fuel-free agenda. The farm represented one possible way of getting out of the current system whereby all produced vegetables are trucked to the south of Sweden to be repacked and trucked north again (these were considered unnecessary journeys and affected the freshness of the produce). The Högdalen indoor farm challenged the system just right, as IP3 expressed it:

"This kind of disruptive entity that we represent out in the periphery in Högdalen, we don't have to care [about the larger system], that's why we can test this in such a way." (IP3)

The aim of the indoor farm was to contribute to the local provision of lettuce and other produce suitable for cultivation, albeit on a very small scale. The amount of lettuce produced was only a small fraction of the total consumed. The idea was to increase the level of local provisioning of food, and to make consumers aware of this need. In the words of IP3:

"Then I think the willingness to buy locally produced increases, and that's where we need to go again. Not just due to import reasons, but foremost due to environmental reasons. And then we need to transform... from animal foods to vegetarian foods. That we need to do to survive." (IP3)

IP2 mentioned food security in terms of the larger picture, i.e. including private gardens, allotment gardens and farms such as the indoor farm in the food security equation. Many small plots will produce large quantities, he reasoned, but:

"It won't solve food production or anything, but it will still be in a totally new way." (IP2).

He went on to argue that the Högdalen farm could be part of a contingency plan for Stockholm. Thus, while the indoor farm will produce only minor amounts of food, it will still produce something, which would otherwise have had to be produced elsewhere. 
The indoor farm was not a public space in itself, so it could not be used for activities aimed at connecting people with each other, or connecting people and place. However, a lot of the activities that occurred because the farm was in place had the potential to bring about connection. These included market days, a market garden, an exhibition space (some of these things already happened and some things were in the planning stage). IP3 considered the indoor farm as a prolongation and logical continuation of the urban agriculture activities that were established earlier in Högdalen. A few years earlier a community garden had been put into place as an experiment to help break a destructive spiral of vandalism in the area and to make local habitants more involved in their own neighbourhood. The community garden was, and still is, successful. IP3 thought the same development could be hoped for with the indoor farm as well: to start up as a project and later put it into the hands of local residents. NRFH was an important actor in securing the local connection of the project as well as the connection to the political level in the municipality, and contacts with the real estate owner. For NRFH, the indoor farm was one of many things that could help Högdalen commercial centre to develop, and they were willing to participate in any project that could create new jobs and bring about positive change in the area.

Something that all interviewees thought important in relation to the indoor farm project was the fact of doing something instead of only talking about it, i.e. making plans and outlining visions. They considered this important because the idea needed to be tried out, tested and evaluated in real life. As IP3 said, instead of waiting for technically optimal systems:

"It's very important to show, I believe. You can talk about this, that's what I mean. You can talk about this forever, about all pros and cons, but it's not until you see it that you believe it. And it needs to be visualised in a number of such plants. That's what I believe. They have to be very public in that way" (IP3).

Interviewees discussed sustainability transitions of the food system in general. While a single actor would not be able to overhaul the current system, a small project such as the one in Högdalen could help to try out a new kind of distribution network at low risk for all involved actors, they reasoned.

\subsection{Project management and communication}

The project had a robust structure due to the fact that the involved parties had already built up relationships, i.e. they had contact with each other from previous projects and dealings. This made it easier to have regular check-ups. There was a readiness to learn from mistakes. For example, a number of mistakes were made when producing the first batch of lettuce that were corrected in the following rounds. The project group also represented a diversity in terms of expertise and organisational types. As IP2 expressed it:

"It's incredibly nice that there are people in the project who know what they are doing, and have knowledge about the technology [on cultivation]." (IP2)

Many actors were involved in creating the indoor farm. The city of Stockholm was project leader in relation to the funding agency, and it also created the platform for all other actors in the project. The city of Stockholm was also responsible for embedding start-ups in the project (which was part of the overall project beyond establishing the indoor farm itself). The greenhouse company was responsible for farming know-how. NRFH managed the indoor farm in practice with support from IP3.

The interviewees mentioned a number of shared values between actors in the project that set up the indoor farm: an interest in innovation, strong societal commitment and commitment to create jobs, local sustainability, reaching out to new citizen groups, and creating social integration in a place. Collaboration in the project went well due to these shared values, interviewees reasoned. For example, the willingness of the centre real estate owner to invest in Högdalen, to take part in development projects and to work with civil society and the municipality was paramount for the project. Interviewees also thought that the real innovation was not the farm itself (it did not use new techniques) but rather the collaboration between municipalities, businesses, and social entrepreneurs. IP3 was the person keeping the different actors and parts of the project together. As IP1 expressed:

"If we hadn't had him, we wouldn't have made it" (IP1).

To keep all parts of the project together, daily updates were needed. Still, being a social entrepreneur with high flexibility, IP2 thought that communication was slow sometimes, especially via the municipality.

According to IP3, the rationale for a large greenhouse business to take part in the project - it had supplied the equipment and the cultivation know-how - was the opportunity to test new things without risking anything as a company. Due to the small economic margins, the greenhouse business could not afford to run experimental projects itself. The greenhouse business also did not have any capacity to meet its end consumers face-to-face. The real estate owner benefited from increased rental income, since the basement area was being used again. Another benefit was the renewal and improved image of the centre facility, in which the indoor farm played one part. 


\subsection{The potential for scaling and expansion}

There were several different ways in which the indoor farm and the project that set it up could be scaled up. In Högdalen, the indoor farm could be somewhat expanded within the 80 $\mathrm{m}^{2}$ it occupied: for instance, shelves could be put up and a larger diversity of herbs could be planted. In addition - as has been pointed out earlier - activities surrounding and in line with the indoor farm could be expanded by using additional space in the basement and above-ground premises for activities, e.g. producing mushrooms, exhibitions, markets, market garden, restaurant, etc. It would also be possible to move the indoor farm or expand it somewhat, within the range of the commercial centre in Högdalen. IP3 pointed out that it was the small scale of the indoor farm that was its rationale. A largescale indoor farm (as other actors have developed in Stockholm city) would not offer any benefits over a largescale conventional greenhouse, he reasoned.

Another type of scaling up would be to implement the indoor farm concept in other places with unused urban resources (such as indoor space). In order for this to work, IP3 thought it imperative that real estate owners had an interest, and that logistics had the potential to work well.

IP2 thought that the governance model whereby social entrepreneurs, businesses and municipalities work together, could and should be scaled up, to repurpose unused urban indoor space on a larger scale. While NRFH were experts on social entrepreneurship and could spread this knowledge to other places, IP2 pointed out:

"The concept is local to us, if it were to be taken to new places it needs to be local. So, it's not us [NRFH] doing it in other places" (IP2).

\subsection{GHG emissions}

Table 4 presents the results from the calculations of GHG emissions from four types of lettuce delivered to Högdalen. As can be seen, the lowest emissions come from the lettuce grown in the open in Sweden, although it is transported about $600 \mathrm{~km}$. The lettuce grown in Högdalen also has low emissions, especially compared to the high-emitting lettuce from greenhouses heated with natural gas as is common in the Netherlands. In Högdalen, as the electricity used was based solely on nuclear, hydro and wind power the resulting emissions were very low. Also, the need for heating the Högdalen facility was low. The Spanish lettuce has higher emissions than the lettuce from Högdalen but lower than the Dutch due to no emissions from heating and lighting.

\subsection{Assessment of the indoor farm}

The assessment of the indoor farm according to the Brunori et al. (2016) framework is presented in Table 5. The assessment is elaborated in the discussion below.

\section{Discussion}

Urban food movements and urban agriculture initiatives often emerge as a reaction to the unsustainability of the food system that currently dominates food provisioning (Thomaier et al. 2015). However, these urban agriculture alternatives are not sustainable per se, and assessments need to be made (ibid).

In terms of the GHG emissions from the indoor farm in Högdalen, we have seen that the choice of emissions factors for the electricity generation is of utmost importance for the outcome. For lettuce grown indoors, there is high electricity use for lighting and even heating in such facilities. We assumed a very low emissions factor based on the electricity company's declaration of the origin of what was bought ( $6.3 \mathrm{~g}$ of $\mathrm{CO} 2$ equivalents per $\mathrm{kWh})$. This may be compared to what was used by Shiina et al. (2011): $378 \mathrm{~g}$ of CO2 equivalents per $\mathrm{kWh}$, or by Molin and Martin (2018): $100 \mathrm{~g}$ of CO2 equivalents per kWh. In Sweden, as well in several other Nordic countries, a major part (more than $90 \%$ ) of the electricity is generated by hydro- and nuclear power, resulting in low emissions. According to the Swedish Environmental Protection Agency, $13 \mathrm{~g}$ of $\mathrm{CO} 2$ equivalents per $\mathrm{kWh}$ is emitted from Swedish electricity production and about $50 \mathrm{~g}$ for Nordic electricity mix (Energi och klimatrådgivningen 2019). Whether or not this means that indoor farming should only be promoted in situations where there is access to low-emitting power sources can be discussed, and whether it is at all adequate to use large amounts of electricity for lighting when crops can use sunlight, albeit only during part of the year in a Nordic country like Sweden. However, our study shows that growing food indoors in cities may be a viable option compared with importing them from far away or growing them in heated greenhouses, given that there is low-emitting electricity available. In other cases, vegetables produced indoors are most probably less climate friendly than other types of vegetables available on the market. We recognise that our study has limits as it has not included the infrastructure needed for city farms. Including that in an analysis requires some thought for how to allocate emissions due to construction of the buildings used for growing, either e.g. in basements or on rooftops of existing houses. In our study, a part of a garage constructed in the 1960ties was used and when the lettuce production started the garage 
Table 4 Greenhouse gas emissions from four types of lettuce available in Högdalen, Stockholm. Emission in $\mathrm{kg}$ of CO2 equivalents per kg lettuce

\begin{tabular}{lllll}
\hline Type of lettuce & \multicolumn{2}{l}{ Part of the life cycle } & & \multirow{2}{*}{ Total, kg per kg } \\
\cline { 2 - 5 } & Cultivation, kg per kg & Transport, kg per kg & Wholesaler and retailer, kg per kg \\
\hline Högdalen indoor farm & 0.36 & 0.00 & 0.00 & 0.10 \\
In the open, Sweden & 0.09 & 0.07 & 0.10 & 0.36 \\
Unheated greenhouse, Spain & 0.09 & 0.37 & 0.10 & 0.56 \\
Heated greenhouse, Netherlands & 2.40 & 0.17 & 2.67 \\
\hline
\end{tabular}

was unused. Thus, from a resource efficiency and pollution perspective, the indoor farm in Högdalen scored + and ++ respectively. Closely connected to resource use is the issue of food waste $(+++)$. While waste was not directly measured in this study, the fact that the lettuce was used in the two cafés run by the NRFH placed directly above the indoor farm or one subway station away indicates that waste should have been possible to keep to a minimum.

The Högdalen farm operated independently of weather and of fossil fuel-based transport for distribution. However, it was vulnerable to power cuts. Some circularities were built in into the production system: water was circulated in the cultivation chamber, $\mathrm{CO} 2$ was taken from the commercial centre above ground, plastic pots were reused (not sold with the salad or discarded as in conventional greenhouses), and most importantly, previously unused indoor urban space was put into use. More circularities could be introduced, however. For example, the connection to the biochar plant in Högdalen could be developed, and use of nutrients originating in urban areas could be introduced. According to Höök and Jonsson (2018), the indoor farm has influenced the resilience of the Högdalen centre facility in positive ways: it has created job opportunities, brought empty buildings into use, and created meeting places (indirectly through other activities in connection to the farm). At the same time, on the level of the cultivation as such, the farm was heavily dependent on all inputs, electricity and inflow of water. Taken as a whole, the farm scored + for resilience.

The indoor farm was small in scale and did not produce any large quantities of food, and could not be claimed to contribute to food supply in Högdalen or in Stockholm. However, food was produced, that would otherwise have had to have been imported to the area (food security score + ). The indoor farm in Högdalen could be seen as a small part of the jigsaw puzzle of urban agriculture in Stockholm, which also includes private gardens, allotment gardens, conventional greenhouses and community gardens. The local willingness to buy the lettuce depended on local production and the innovativeness of production, in contrast to other findings where consumers were sceptical about "unnatural" food from indoor production (Specht et al. 2016; Kalantari et al. 2017). The reasons could be the high degree of transparency (in the same building), and that food produced in these novel ways are not common in Sweden. There are some upcoming projects, but no robust studies have been made on consumers' perspectives yet. The willingness to buy the Högdalen lettuce and the large consumer and retailer interest renders the score +++ for "consumer behaviour" and ++ for "territoriality".

In conventional urban development, landscape architects, architects and construction companies often do not

Table 5 Assessment of the indoor farm with the Brunori et al. (2016) framework

\begin{tabular}{|c|c|c|c|c|}
\hline Economic & Social & Environmental & Health & Ethical \\
\hline Affordability +++ & Food security + & Resource use + & Nutrition no information & $\begin{array}{l}\text { Animal welfare no } \\
\text { information }\end{array}$ \\
\hline $\begin{array}{l}\text { Creation } \& \text { distribution of added value } \\
+++\end{array}$ & $\begin{array}{l}\text { Consumer behaviour } \\
+++\end{array}$ & Pollution ++ & $\begin{array}{l}\text { Food safety no } \\
\text { information }\end{array}$ & Responsibility ++ \\
\hline Economic development ++ & Territoriality ++ & Biodiversity $-/+$ & $\begin{array}{l}\text { Traceability no } \\
\text { information }\end{array}$ & Fair trade no information \\
\hline Efficiency ++ & Connection + & $\begin{array}{l}\text { Technological innovation } \\
-/+\end{array}$ & & $\begin{array}{l}\text { Information \& communication } \\
++\end{array}$ \\
\hline $\begin{array}{l}\text { Profitability + } \\
\text { Resilience + }\end{array}$ & Labour relations + & Food waste +++ & & Governance +++ \\
\hline
\end{tabular}


communicate. Innovative Zfarming requires interdisciplinary exchanges and networks among actors that have not cooperated before (Thomaier et al. 2015). This was one of the success factors in Högdalen. Collaboration between real estate owners, municipalities, greenhouse businesses and new urban agriculture initiatives and the social entrepreneurial sector was the innovation in the project that established the indoor farm (governance +++ ; information \& communication ++ ). Previous projects and contacts played a role when setting up the project and successfully carrying it out. The indoor farm would not have been as successful without this pre-history. Strong shared values guiding the collaboration were important. The indoor farm, and the renewed use of the premises where the farm was situated, could be seen as a catalyst for other activities in Högdalen (creation and distribution of added value +++; economic development ++ ; profitability + ). The farm had the potential to contribute to new meeting places and created stronger links to Högdalen as a place for its inhabitants $($ connection +$)$. At the same time, the indoor farm did not create meeting places in itself, as an outdoor, land based urban community farm could (Firth et al. 2011).

The project managed to set up the indoor farm with relatively small means and the lettuce was not more expensive than conventional greenhouse lettuce (affordability +++). This stands in contrast to other similar projects, which are often challenged by high initial costs (Specht et al. 2014; Al-Kodmany 2018). It is possible to see the small indoor farm in Högdalen in the light of the need for innovations in this field and the need to develop new knowledge about innovations that seem promising but where there is little data. To build something, test it, and draw conclusions is better than waiting for optimised and "perfect" systems. The indoor farm in Högdalen was not technically optimised - and much could be improved - but it showed that it is possible to do something with relatively small means if actors collaborate and push in the same direction (technical innovation $-/+$ ).

The indoor farm created work, but not full-time employment. However, being in a basement, it was not an ideal work environment, and a full-time employed person should not spend a lot of time in the cultivation chamber itself (labour relations +). Contrary to this, Al-Kodmany (2018) claims that work in indoor farms could be attractive for technologically minded generations (Al-Kodmany 2018). In the case of Högdalen, the work of cultivation needed to be combined with other tasks such as communication, marketing and selling.

There were various ways in which the indoor farm could be scaled up without losing the attributes contributing to sustainability. For example, more crops could be included in the cultivation chamber and additional activities in connection to the farm could be introduced. These might include a market garden, green walls, a café, and/or exhibition space. The indoor farm could also be introduced in other places where under-used urban resources are available and where a smooth collaboration between partners is possible.

\section{Conclusion}

The main contribution of this article is that a real case of an indoor farm was assessed for a number of sustainability impacts. Thus, there is a value in including a range of sustainability attributes when assessing real cases. While single cases are never representative, they provide insights that can contribute to the larger picture. It was possible to make this assessment since the Högdalen indoor farm was publicly funded and the actors were open and willing to have researchers in their team. In many other cases, indoor farms are commercial actors, not ready to share business details with research. Thus our study was a real assessment, albeit limited, and was not based on claims made by commercial companies (cf. Beacham et al. 2019). We found the Högdalen indoor farm largely sustainable based on the aspects assessed in this study.

This said, the farm did not contribute to food security, for two main reasons: it is very small and it produces lettuce which is not a bulk food item necessary for food provisioning of the population. Thus, even if the cultivation was scaled up to provide all lettuce needed in Stockholm, other food items are more vital for food security. At the same time, the Högdalen indoor farm did contribute to sustainable urban development in a number of ways: by the good cooperation between commercial, public and civil society partners, by the use of unused urban space, by the aim to create jobs, by the link to circular flows in the city and by the ambition to increase attractivity of a suburban centre in need of just this. Thus, growing lettuce may not be the farm's main contribution. However, without the growing of lettuce, these other amenities would not have materialised in this specific case.

Acknowledgements This research was mainly funded by Vinnova, the Swedish Innovation Agency. The authors thank the reviewer and editor for their constructive comments.

Funding Information Open access funding provided by Royal Institute of Technology.

\section{Compliance with ethical standards}

Conflict of interest The authors declare that they have no conflict of interest. 


\section{Appendix 1}

\begin{tabular}{|c|c|}
\hline $\begin{array}{l}\text { Attribute from Brunori et al. } \\
\text { (2016) }\end{array}$ & Description of the attribute derived from Brunori et al. (2016), and authors' interpretation \\
\hline Affordability & the cost of the products and who can buy and access them \\
\hline $\begin{array}{l}\text { Creation and distribution of } \\
\text { added value }\end{array}$ & $\begin{array}{l}\text { how the value of the products increases by different production techniques/processing/qualities, and which actor(s) } \\
\text { benefit(s) from this value increase }\end{array}$ \\
\hline Economic development & e.g. revenues \\
\hline Efficiency & resource use in relation to output \\
\hline Profitability & no specific description in Brunori et al. (2016) \\
\hline Resilience & $\begin{array}{l}\text { how robust the system is; how well it can handle change and disturbance. The system in this case refers to the indoor } \\
\text { farm, the project developing the farm, and the city district in which the farm is situated }\end{array}$ \\
\hline Food security & how the production system contributes to food provisioning in the city \\
\hline Consumer behaviour & consumer use, willingness to pay \\
\hline Territoriality & how place influences the product and the will of consumers to purchase it \\
\hline Connection & how the product can be used to connect people, and to connect people with a place \\
\hline Labour relations & how workers are treated in the system, including matters of social justice \\
\hline Resource use & direct and indirect use of resources, e.g. fossil fuels \\
\hline Pollution & emissions from the value chain \\
\hline Biodiversity & e.g. diversity of crops \\
\hline Technological innovation & e.g. use of innovations to reduce pollution or waste \\
\hline Food waste & no specific description in Brunori et al. (2016) \\
\hline Nutrition & nutritional content of the foods produced \\
\hline Food safety & food safety standards and controls, artificial additives \\
\hline Traceability: & no specific description in Brunori et al. (2016) \\
\hline Animal welfare & e.g. animal density \\
\hline Responsibility & which actors are responsible/take responsibility for what in the value chain \\
\hline Fair trade & no specific description in Brunori et al. (2016) \\
\hline Information \& communication & the availability of information and communication in the chain \\
\hline Governance & how the food system is governed, managed and controlled \\
\hline
\end{tabular}


Open Access This article is licensed under a Creative Commons Attribution 4.0 International License, which permits use, sharing, adaptation, distribution and reproduction in any medium or format, as long as you give appropriate credit to the original author(s) and the source, provide a link to the Creative Commons licence, and indicate if changes were made. The images or other third party material in this article are included in the article's Creative Commons licence, unless indicated otherwise in a credit line to the material. If material is not included in the article's Creative Commons licence and your intended use is not permitted by statutory regulation or exceeds the permitted use, you will need to obtain permission directly from the copyright holder. To view a copy of this licence, visit http://creativecommons.org/licenses/by/4.0/.

\section{References}

Al-Kodmany, K. (2018). The vertical farm: A review of developments and implications for the vertical city. Buildings, 8(2), 24.

Astee, L. Y., \& Kishnani, N. T. (2010). Building integrated agriculture: Utilising rooftops for sustainable food crop cultivation in Singapore. Journal of Green Building, 5(2), 105-113.

Agrilyst. (2017). State of Indoor Farming 2017. Retrieved from www. agrilyst.com/stateofindoorfarming2017/

Banerjee, C., \& Adenaeuer, L. (2014). Up, up and away! The economics of vertical farming. Journal of Agricultural Studies, 2(1), 40-60.

Barthel, S., Folke, C., \& Colding, J. (2010). Social-ecological memory in urban gardens - Retaining the capacity for management of ecosystem services. Global Environmental Change, 20(2), 255-265.

Barthel, S., Parker, J., \& Ernstson, H. (2015). Food and green space in cities: A resilience lens on gardens and urban environmental movements. Urban Studies, 52(7), 1321-1338.

Bauduceau, N., Berry, P., Cecchi, C., Elmqvist, T., Fernandez, M., \& Hartig, T., (2015). Towards an EU research and innovation policy agenda for nature-based solutions \& re-naturing cities: Final report of the horizon 2020 expert group on 'Nature-based solutions and renaturing Cities'. https://doi.org/10.2777/765301.

Beacham, A. M., Vickers, L. H., \& Monaghan, J. M. (2019). Vertical farming: A summary of approaches to growing skywards. The Journal of Horticultural Science and Biotechnology, 94(3), 277-283.

Benke, K., \& Tomkins, B. (2017). Future food-production systems: Vertical farming and controlled-environment agriculture. Sustainability: Science, Practice and Policy, 13(1), 13-26.

Berghöfer, A., Mader, A., Patrickson, S., Calcaterra, E., Smit, J., Blignaut, J., et al. (2011). TEEB manual for cities: Ecosystem services in urban management. Suiza: The Economics of Ecosystems and Biodiversity.

Bolund, P., \& Hunhammar, S. (1999). Ecosystem services in urban areas. Ecological Economics, 29(2), 293-301.

Bohn, K., \& Viljoen, A. (2011). The edible city: Envisioning the continuous productive urban landscape (CPUL). Field, 4(1), 149-161.

Bonow, M., \& Normark, M. (2018). Community gardening in Stockholm: Participation, driving forces and the role of the municipality. Renewable Agriculture and Food Systems, 33(6), 503-517.

Brunori, G., Galli, F., Barjolle, D., van Broekhuizen, R., Colombo, L., Giampietro, M., Kirwan, J., Lang, T., Mathijs, E., Maye, D., de Roest, K., Rougoor, C., Schwarz, J., Schmitt, E., Smith, J., Stojanovic, Z., Tisenkopfs, T., \& Touzard, J.-M. (2016). Are local food chains more sustainable than global food chains? Considerations for assessment. Sustainability, 8, 449.

Burgos, S., \& Stapel, M. (2018). CO2 emissions scoping report. The Netherlands: Comparison between different farming methods in lettuce production. Onefarm B.V.
Clark, K. H., \& Nicholas, K. A. (2013). Introducing urban food forestry: A multifunctional approach to increase food security and provide ecosystem services. Landscape Ecology, 28(9), 1649-1669.

Despommier, D. (2010). The vertical farm: Feeding the world in the 21st century. Macmillan.

Despommier, D. (2009). The rise of vertical farms. Scientific American, $301(5), 80-87$.

Dutch Greenhouses (2020) Heating greenhouses https:// dutchgreenhouses.com/technology/heating. Accessed $10^{\text {th }}$ of January 2020.

Eigenbrod, C., \& Gruda, N. (2015). Urban vegetables for food security in cities. A review. Agronomy for Sustainable Development, 35(2), 483-498.

Energi och klimatrådgivningen, (2019). https://energiradgivningen.se/ klimat/miljopaverkan-fran-el. Accessed 2nd of May 2019.

Finn, D. (2014). DIY urbanism: Implications for cities. Journal of Urbanism: International Research on Placemaking and Urban Sustainability, 7(4), 381-398.

Firth, C., Maye, D., \& Pearson, D. (2011). Developing "community" in community gardens. Local Environment, 16(6), 555-568.

Germer, J., Sauerborn, J., Asch, F., de Boer, J., Schreiber, J., Weber, G., \& Müller, J. (2011). Skyfarming: An ecological innovation to enhance global food security. Journal für Verbraucherschutz und Lebensmittelsicherheit, 6(2), 237-251.

Gómez-Baggethun, E., \& Barton, D. N. (2013). Classifying and valuing ecosystem services for urban planning. Ecological Economics, 86, 235-245.

Gould, D., \& Caplow, T. (2012). Building-integrated agriculture: A new approach to food production. In Metropolitan Sustainability (pp. 147-170). Woodhead publishing.

Graamans, L., Baeza, E., Van Den Dobbelsteen, A., Tsafaras, I., \& Stanghellini, C. (2018). Plant factories versus greenhouses: Comparison of resource use efficiency. Agricultural Systems, 160, $31-43$.

Grewal, S. S., \& Grewal, P. S. (2012). Can cities become self-reliant in food? Cities, 29(1), 1-11.

Hale, J., Knapp, C., Bardwell, L., Buchenau, M., Marshall, J., Sancar, F., \& Litt, J. S. (2011). Connecting food environments and health through the relational nature of aesthetics: Gaining insight through the community gardening experience. Social Science \& Medicine, 72(11), 1853-1863.

Hortidaily (2019). World greenhouse vegetable statistics updated for 2019. Available at: https://www.hortidaily.com/article/9057219/ world-greenhousevegetable-statistics-updated-for-2019/. Accessed May 192020.

Hospido, A., Milai Canals, L., McLaren, S., Truninger, M., EdwardsJones, G., \& Clift, R. (2009). The role of seasonality in lettuce consumption: A case study of environmental and social aspects. International Journal of Life Cycle Assessment, 14, 381-391.

Höök, L. and K. Jonsson. (2018). Resiliensanalys av Högdalen centrum [resilience assessment of the Högdalen commerical Centre]. Bachelor thesis, Royal Institute of Technology - KTH. Stockholm. Available at: http://kth.diva-portal.org

IPCC (2018). Summary for Policymakers. In: Masson-Delmotte, V., Zhai, P., Pörtner, H. O., Roberts, D., Skea, J., Shukla, P. R., Pirani, A., Moufouma-Okia, W., Péan, C., Pidcock, R., Connors, S., Matthews, J. B. R., Chen, Y., Zhou, X., Gomis, M. I., Lonnoy, E., Maycock, T., Tignor, M., \& Waterfield, T. (eds). (2018). Global warming of $1.5^{\circ} \mathrm{C}$. An IPCC Special Report on the impacts of global warming of $1.5^{\circ} \mathrm{C}$ above pre-industrial levels and related global greenhouse gas emission pathways, in the context of strengthening the global response to the threat of climate change, sustainable development, and efforts to eradicate poverty. World Meteorological Organization, Geneva, Switzerland.

Jernkontoret. (2018). Emissionsfaktorer för bränslen och energislag. 
Kalantari, F., Mohd Tahir, O., Mahmoudi Lahijani, A., \& Kalantari, S. (2017). A review of vertical farming technology: A guide for implementation of building integrated agriculture in cities. In Advanced Engineering Forum (Vol. 24, pp. 76-91). Trans tech publications.

Krewer, Emanuelsson och Zettergren. (2013). LCA of food transports and tomato production. A comparison of different food transports scenarios, including production of tomatoes.

Lovell, S. T. (2010). Multifunctional urban agriculture for sustainable land use planning in the United States. Sustainability, 2(8), 2499-2522.

LRF. (2003). Maten och miljön. Livscykelanalys av sju livsmedel.

McLain, R., Poe, M., Hurley, P. T., Lecompte-Mastenbrook, J., \& Emery, M. R. (2012). Producing edible landscapes in Seattle's urban forest. Urban Forestry \& Urban Greening, 11(2), 187-194.

Molin, E., \& Martin, M. (2018). Assessing the energy and environmental performance of vertical hydroponic farming. Stockholm: IVL.

Mok, H. F., Williamson, V. G., Grove, J. R., Burry, K., Barker, S. F., \& Hamilton, A. J. (2014). Strawberry fields forever? Urban agriculture in developed countries: A review. Agronomy for Sustainable Development, 34(1), 21-43.

Morgan, K. (2015). Nourishing the city: The rise of the urban food question in the global north. Urban Studies, 52(8), 1379-1394.

NTM, Nätverket för transporter och miljö. (2018). https://www. transportmeasures.org/ntmcalc/v4/basic/index.html\#/ Available on the 29th of December 2018.

Orsini, F., Gasperi, D., Marchetti, L., Piovene, C., Draghetti, S., Ramazzotti, S., Bazzocchi, G., \& Gianquinto, G. (2014). Exploring the production capacity of rooftop gardens (RTGs) in urban agriculture: The potential impact on food and nutrition security, biodiversity and other ecosystem services in the city of Bologna. Food Security, 6(6), 781-792.

RUFS (2018) Regional utvecklingsplan för Stor Stockholmsregionen http://www.rufs.se/publikationer/2018/rufs-2050/ (accessed 20190422).

Semilla, M. G., Agulto, I., Espino, A., \& Sicat, E. (2018). Indoor production of loose-leaf lettuce (Lactuca sativa L.) using artificial lights and cooling system in tropical lowland. In MATEC Web of Conferences (Vol. 192, p. 03016). EDP sciences.

Shiina, T., Hosokawa, D., Roy, P., Orikasa, T., \& Thammawong, M. (2011). Life cycle inventory analysis of leafy vegetables grown in two types of plant factories. Acta Horticulturae, 919, 115-122.

Specht, K., Siebert, R., Hartmann, I., Freisinger, U. B., Sawicka, M., Werner, A., Thomaier, S., Henckel, D., Walk, H., \& Dierich, A. (2014). Urban agriculture of the future: An overview of sustainability aspects of food production in and on buildings. Agriculture and Human Values, 31(1), 33-51.

Specht, K., Siebert, R., \& Thomaier, S. (2016). Perception and acceptance of agricultural production in and on urban buildings (ZFarming): A qualitative study from Berlin, Germany. Agriculture and Human Values, 33(4), 753-769.

Swahn, M. (2008). DRAFT additional CO2e-factors in goods transport. NTM. Available at https://www.transportmeasures.org/wp-content/ uploads/2015/11/Additional-energy-use-in-transport-sector20080611-rev-20102411.pdf.

Swedish Allotment Garden Society (2019). https://fssk.se/ (accessed 20190422).

Thomaier, S., Specht, K., Henckel, D., Dierich, A., Siebert, R., Freisinger, U. B., \& Sawicka, M. (2015). Farming in and on urban buildings: Present practice and specific novelties of zero-acreage farming (ZFarming). Renewable Agriculture and Food Systems, 30(1), 43-54.

Uppsäll, P., \& K. Enges. (2018). Framtidens stadsnära odling: En fallstudie av stadsnära underjordisk odling. [future urban farming: A case study of urban underground farming]. Bachelor thesis, Royal Institute of Technology - KTH. Stockholm. Available at: http://kth. diva-portal.org

Viljoen, A., \& Bohn, K. (2014). Second nature urban agriculture: Designing productive cities. Routledge.

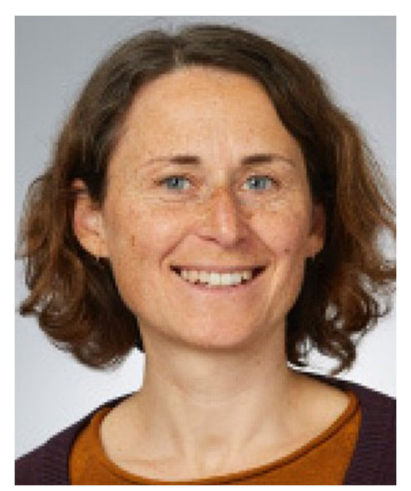

Rebecka Milestad is a researcher in sustainable food systems with a focus on local organic networks

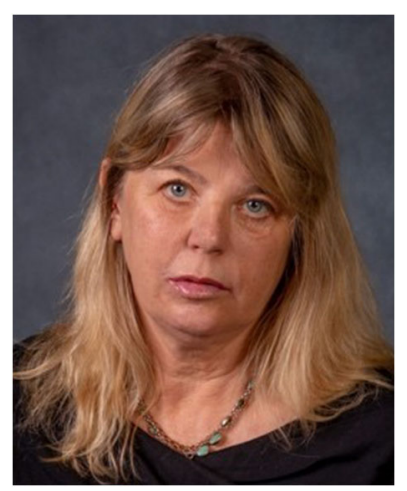

Annika Carlsson-Kanyama is a researcher specialized in system studies of the environmental impacts of food and food consumption patterns as well as adaptation to climate change.

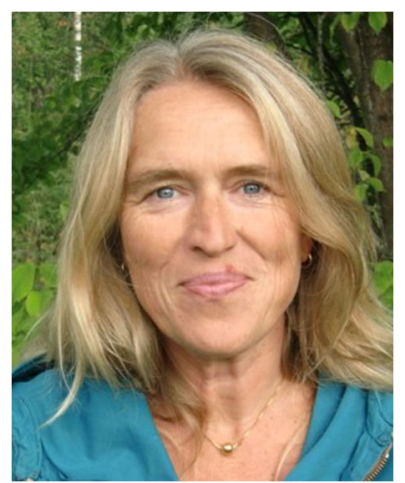

Christina Schaffer has a MSc in Systems Ecology and 20 years of experience from sustainable development and urban agriculture. 